Zeit die Periode sich constant gehalten hat, so spricht doch die Vergleichung einer gleichmässigen Periode von

$$
3^{\mathrm{d}} 23^{\mathrm{h}} 49^{\mathrm{m}} 3^{2} \cdot{ }^{\mathrm{s}} \text { zwischen zwei geraden Epochen }
$$

mit den wenigen aus verschiedenen Jahren vorhandenen Grössenschätzungen des Sterns zu Gunsten einer ziemlichen Regelmässigkeit der Periode. Lässt man für die Potsdamer Beobachtungen die Messung vor das Minimum fallen, statt wie bei der Vergleichung in A. N. 3253 sie nach dem Minimum anzunehmen, so wird mit dieser etwas kleineren Periode neben der Engelmann'schen Grössenschätzung von I870 Juli I 4 nicht nur die Potsdamer Messung von r888 Juni I, sondern auch die Messung in Cambridge mit dem Meridianphotometer von $1886 \mathrm{Juli} 3 \mathrm{zu} \quad 7^{\mathrm{m}} \cdot 5$, die dem Hauptminimum der Epoche - I 500 sehr nahe liegt, äusserst befriedigend dargestellt. Die Cambridger Messung von I 885 Aug. $8 \mathrm{zu} 7 \mathrm{~m}_{1}$ liegt der ungeraden Epoche $-\mathrm{I}_{6} 66_{3}$ nahe und gehört wohl schon dem grössten Lichte des Veränderlichen an.

Die Vergleichung der vorhandenen Beobachtungen des Veränderlichen im kleinen Lichte mit der Periode $3^{\mathrm{d}} 23^{\mathrm{h}} 49^{\mathrm{m}} 3^{2} \cdot 7$ zwischen zwei geraden Epochen gestaltet sich so, wenn alle Zeiten auf die Sonne reducirt und in M.Z. Bamberg ausgedrückt werden und eine verbesserte Lichtcurve zu Grunde gelegt wird:

\begin{tabular}{|c|c|c|c|c|c|}
\hline & & & Red. & Ep. & $R-B$ \\
\hline Leipzig & I $870 \mathrm{Juli}$ & I 4.434 & +0.080 & -4422 & - o. 060 \\
\hline Cambridge & 1886 & 3.693 & +0.100 & -1500 & +0.054 \\
\hline Potsdam & I888 Juni & 1.486 & +0.090 & - I I 50 & 0.000 \\
\hline Potsdam & I 89 I Oct. & 6.277 & +0.076 & $-53^{8}$ & +0.002 \\
\hline Potsdam & 189 I Nov. & $3.200 ?$ & +0.102 & $-\quad 5^{24}$ & +0.002 \\
\hline Bamberg & I $894 \mathrm{Mai}$ & 29.493 & +0.100 & 54 & +0.005 \\
\hline Bamberg & 1894 Aug. & $5 \cdot 4^{85}$ & -0.030 & - & +0.020 \\
\hline
\end{tabular}

\begin{tabular}{|c|c|c|c|c|c|}
\hline & \multicolumn{3}{|c|}{ Minima } & Ep. & $R-B$ \\
\hline Bamberg & I 894 & Sept. & 10.386 & -2 & $\left.+0.023^{*}\right)$ \\
\hline Bamberg & I 894 & $»$ & 14.402 & $\circ$ & 0.000 \\
\hline Leiden 1 . Prag & 1894 & $»$ & I 8.390 & +2 & +0.005 \\
\hline Leiden & 1894 & $》$ & 22.385 & +4 & +0.002 \\
\hline Bamberg & I 894 & $\gg$ & $26.3^{85}$ & +6 & -0.005 \\
\hline Bamberg & I 894 & $»$ & 30.379 & +8 & -0.006 \\
\hline
\end{tabular}

*) Sept. Io nur eine Vergleichung.

Die angegebene Periode scheint demnach der Wahrheit schon sehr nahe zu kommen. Da die Vergleichsterne sehr günstig zu dem Veränderlichen gelegen sind und dieser von a Ophiuchi aus auch ohne Kreise sehr leicht aufzusuchen ist, wodurch die Vergleichungen noch in heller Dämmerung begonnen werden können, so können die Hauptminima noch einige Zeit lang auch mit gewöhnlichen Tuben aus Abnahme und Zunahme des Lichtes bestimmt werden. Die ganz sicher vorhandenen secundären Minina dagegen lassen sich in Mitteleuropa nur dem allerletzten Reste nach noch bemerken.

Bamberg 1894 Oct. 7 .

Ernst Hartwig.

\title{
Schreiben von Herrn S. C. Chandler an Prof. H. Kreutz betr. Z Herculis.
}

With reference to your letter of Sept. $22 *$ ) it may be well to explain the facts with regard to this star, which has been known here as a variable of the Algol-type, to several astronomers interested in the subject, ever since the latter part of July or the beginning of August. I had discovered it to be such from minima observed on July 28 and Aug. 5, and had communicated it to Yendell, Sawyer, Dr. Frost and others, on Aug. 5. Yendell in a few days confirmed it, and I, having meanwhile observed other minima (five in all), determined its elements of minimum, I 894 Aug. $5^{\mathrm{d}} \mathrm{I}_{2}^{\mathrm{b}} 14^{\mathrm{m}}$ M. T. Gr. $+3^{\mathrm{d}} 23^{\mathrm{h}} 50^{\mathrm{m}} . \mathrm{O} \mathrm{E}$, and assigned the notation $644^{2}$ $\mathrm{Z}$ Herculis about the middle of August, on the confirmation by Yendell. Since the minima were increasingly difficult to observe in this longitude, on account of advance into the evening twilight (indeed only the increase of the star had been seen here), I communicated all the facts, together with the above elements, with an ephemeris running up to the beginning of November, to Prof. Müller and Dr. Kempf on Aug. 26, and to Prof. Dunér on Aug. 29, in the hope that those observers would secure some observations of minima before the star got too near the sun. If my letters reached Potsdam and Upsala as they should have done, I estimated that the minima from Sept. ro forward could be observed there, or at least that they would communicate with other observers who would take the star under observation. I stated in my letter to Dunér that Yendell had confirmed it. You are at liberty to print this letter, if you desire, and think it is worth while. In addition I may say, as bearing on the very interesting discovery of Duner that the minima follow each other at unequal intervals of $47^{\mathrm{b}}$ and $49^{\text {h }}$, that my observations, which began July 22 and ended Aug. 23 ( $3^{6}$ in number), excluded the hypothesis that the period could be one-half that above assigned, but do not exclude a minimum which should occur a few hours previous to the time midway between; and so far, therefore, are in harmony with the unequal intervals which his observations show.

I desire to add also that I was led to observe this star by the note of Prof Müller and Dr. Kempf, on p. 482 of their catalogue, which called attention to the discordance of their measurements and remarked that these stars $(2404$ and 2405 ) deserve watching.

\section{S. C. Chandler.}

*) Der Brief enthielt die Mittheilung der Entdeckung des veränderlichen Sterns $Z$ Herculis durch Dr. E. Hartwig. $K r$. 